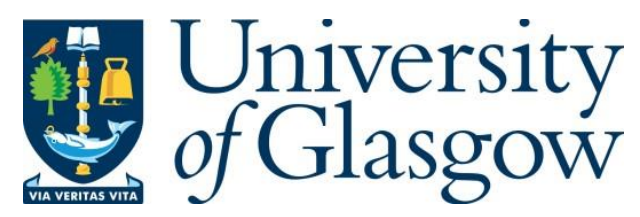

Tomlinson, J. (2019) Churchill's defeat in Dundee, 1922, and the decline of liberal political economy. Historical Journal, (Accepted for Publication).

There may be differences between this version and the published version. You are advised to consult the publisher's version if you wish to cite from it.

http://eprints.gla.ac.uk/192576/

Deposited on: 9 August 2019

Enlighten - Research publications by members of the University of Glasgow http://eprints.gla.ac.uk 


\title{
Churchill's defeat in Dundee, 1922, and the decline of liberal political economy
}

\author{
JIM TOMLINSON
}

University of Glasgow

\section{Churchill's defeat}

Abstract: This article uses Churchill's defeat in Dundee in 1922 to examine the challenges to liberal political economy in Britain posed by the First World War. In particular, the focus is on the impact of the war on re-shaping the global division of labour and the difficulties in responding to the domestic consequences of this reshaping. Dundee provides an ideal basis for examining the links between the local politics and global economic changes in this period because of the traumatic effects of the war and on the city. Dundee depended to an extraordinary extent on one, extremely 'globalised' industry, jute, for its employment. All raw jute brought to Dundee came from Bengal, and the markets for its product were scattered all over the world. Moreover, the main competitive threat to the industry came from a much poorer economy (India) so that jute manufacturing was the first major British industry to be significantly affected by low wage competition. Before 1914 the Liberals combined advocacy of free trade with a significant set of interventions in the labour market and in social welfare, including Trade Boards. The Dundee case allows us to examine in detail the responses to post-war challenges to these Liberal orthodoxies.

In 1922, after 14 years as one of the city’s two MPs, Churchill was defeated as Liberal candidate for Dundee. ${ }^{1}$ For Churchill this was a key moment in his personal political biography, almost the last occasion on which he stood as a Liberal candidate as he began his journey back to the Conservative party. ${ }^{2}$ It was also a key moment in the parliamentary politics of the city, with Churchill the last Liberal to be elected, so 1922 marked the final moment of the shift from a position of Whig/Liberal dominance, which had endured since the 1832 Reform Act, to a Labour predominance which was to last most of the twentieth century. ${ }^{3}$ But beyond these two particular trajectories, Churchill's defeat can be used to examine a broader issue: the challenges to liberal political economy in Britain in the context of the First World War. ${ }^{4}$ In particular, the 
focus here is on the impact of the war on re-shaping the global division of labour and, above all, the difficulties in responding to the domestic consequences of this reshaping.

Dundee is ideal for use as a basis for an examination of the links between the local politics and global economic changes in this period because of the traumatic effects of the war and its aftermath for the economic vitality of the city. That vitality depended to an extraordinary extent on one industry, jute, which provided directly and indirectly most of the city’s employment. Jute was an extremely 'globalised' industry. All raw jute brought to Dundee came from Bengal, and the markets for its product were scattered all over the world. But in addition, the main competitive threat to the industry came from a much poorer economy (India) so that jute manufacturing was the first major British industry to be significantly affected by low wage competition. Adding further complexity to this global entanglement was that India was, of course, part of the British Empire, so that the challenge of responding to the industry's problems was necessarily embedded in imperial strategies and policies. ${ }^{5}$

The war greatly accelerated the trends that were already evident in the jute industry well before 1914. Significant competition from jute factories in Bengal had been evident since the 1880s, although the Dundee industry continued to expand, albeit slowly, until the eve of war. The question of how to respond to this competition had been live in the city from that decade onwards, and many of the city's employers had shifted to a protectionist stance. But that stance had found little support in the wider electorate, and in 1908 Churchill had won on a strongly free trade platform, joining Alexander Wilkie, a Labour MP with broadly ‘Lib-Lab’ affiliations, who had been elected in $1906 .^{6}$ 
In the years before 1914 the Liberals had not just been a free trade party, vital as that was to their political identity. The 'New Liberalism' of those years articulated a combination of free trade with a significant set of interventions in the labour market and in social welfare, designed to attract the urban working class. On the labour market side were the creation of Labour Exchanges, Unemployment (as well as Sickness) Insurance, and Trade Boards to set minimum wages in some sectors of the economy. Social welfare legislation included the provision of pensions and free school meals. ${ }^{7}$

Before 1914 this combination of international liberalism and domestic reform secured power for the Liberals, and defeated the alternative protectionist political economy of the Conservatives, while simultaneously limiting the gains of the Labour Party. ${ }^{8}$ But it came under profound pressure as a result of the First World War, with all the great export staples (textiles, shipbuilding, coal-mining, iron and steel) weakened by the impacts of the war. After a brief boom in 1919/20, their collapse posed compelling questions about the desirability of free trade, but also about how domestic policy would respond to the plight of the people in areas affected by staple decline.

The Dundee case allows us to examine these key themes of the external and internal challenges to pre-war Liberal orthodoxies. In particular, debates in and about the city between Churchill’s victory in the 1918 election and his 1922 defeat highlight the difficulties of formulating answers to the new problem of low wage, imperial competition bringing exceptional levels of economic distress to a major industry. While the electoral problems of the Liberal party in these years stemmed from a variety of causes, not least a divided leadership and the decline of its traditional 
Nonconformist base, this article contends that there were profound problems of political economy that the party failed to effectively respond to. ${ }^{9}$

The first section of this essay provides a summary of the city, its economy and politics from Churchill's first election in 1908 to the coming of war, and the second looks at the impact of the war on the city. The third analyses the external aspect, focussing on the battle between protectionism and free trade, especially in the immediate post-war years. The fourth highlights the key issue of wages and their regulation, in the context of the mass unemployment that emerged after 1920, and the fifth section deals with the run up to and the 1922 election itself. The last section offers some conclusions on the wider implications of the Dundee case for the contemporary problems facing liberal political economy.

At the turn of the twentieth century approximately 40 per cent of Dundee’s working population was employed directly in the jute industry, but many more in the docks, on the railways, in shipping and merchanting, were involved in buying and selling and transporting both the raw material and the finished product. ${ }^{10}$ The term ‘juteopolis’, used of Dundee since the 1850s, accurately described its situation: no other industrial city was so reliant on one sector. ${ }^{11}$

Imported from Bengal, raw jute was manufactured into a coarse cloth used in sacking, bags and related products and sold in markets across the world for the transport of the products central to the 'first great globalization' ${ }^{12}$ By the early twentieth century the strong global demand for these products led to the rise of output in a range of European states (especially Germany) and the USA. The simplicity of 
the product and the unsophisticated technology used in its manufacture gave a huge competitive advantage to low wage producers, and this meant above all the area around Calcutta, where Scottish money, management and expertise had helped to create a machine industry capable of competing in world markets. By the 1890s Calcutta's output overtook that of Dundee, and the two cities dominated world trade in the product (neither industry at this stage sold very much in the home market of their rival).

The strength of responses to this competition in juteopolis waxed and waned, partly depending upon the state of the trade cycle, which had a particularly large impact in jute. From the 1880s the local Chamber of Commerce debated protectionist solutions, though as the competition in jute products was largely confined to third country markets, the likely efficacy of such a policy was unclear. ${ }^{13}$ Alternatives debated included the alignment of Indian with British Factory Acts, to try and force up wage costs in Calcutta. ${ }^{14}$

As in many British industrial cities, so in Dundee, the predominant liberalism of the mid-nineteenth century came under pressure as the staple export trades encountered growing competition in that century's last decades. ${ }^{15}$ Across the country there was much talk of economic 'decline', in many respects exaggerated, but which nevertheless for many called into question commitment to free trade. ${ }^{16}$ However, while many industrial employers moved to Conservative positions, and the Conservatives moved towards protectionism, liberalism as a political force remained predominant in most industrial parts of the country. This was the case in Dundee. Ever since the 1832 Reform Act Dundee had had Liberal MPs (two from 1868), and though a Labour MP was elected for the first time in 1906, he was, as noted above, very much of a 'Lib-Lab’ disposition. 
So when Churchill won Dundee for the first time in 1908 the city was already suffering from a long-run trend of rising Indian competition, and at the time of the election the jute industry was also in one of its periodic depressed stages. Despite this context, Churchill's approach to the election emphasized the continuing case for free trade. A pamphlet made up of his election speeches made clear use of traditional rhetoric about protection threatening to 'allow people for private profit to impose taxation upon bread and meat' which 'will cheat and starve your children'. In his final speech he declaimed 'You know what would be the result of a Tory tariff reform victory...corruption at home, aggression to cover it abroad; the trickery of tariff juggles; the tyranny of a wealth-fed party machine; sentiment by the bucketful— patriotism and Imperialism by the Imperial pint...Dear food for the millions, cheap labour for the millionaire..... ${ }^{17}$

The tone of the Liberal campaign was as much anti-Tory as anti-Labour, focussed on defending free trade, but also on the need for social reform. ${ }^{18}$ Two days before the election the Liberal government legislated for Old Age Pensions (as well as abolishing the Sugar duty) and this chimed with the Liberal claim that social reform could be funded from the proceeds of economic expansion, without recourse to tariffs. Churchill himself offered broad support for social reform in the election, defending the Liberal record on the Trade Disputes Act (which protected trade union action) and pensions, but offering little in the way of specific promises. ${ }^{19}$

Churchill's need for a new parliamentary seat had been brought about by his move from Colonial Under-Secretary to President of the Board of Trade. ${ }^{20}$ It was in the latter role that he was to play a significant role in the 'New Liberal' social reforms. The Board of Trade had a broad responsibility for the labour market, and Churchill was to be important in the passage of the legislation on Labour Exchanges, 
National Insurance, and Trade Boards which set minimum wages in some 'sweated industries. There are divergent views about the extent and depth of Churchill's support for these policies, but there is no doubt that this was the period in his career when he was most concerned with social reform. ${ }^{21}$

In the current context it was the support for Trade Boards that is most significant, given their later importance in the jute industry. On the face of it these represented the most direct assault on liberal economic principles, giving a state body the ability to determine wages. ${ }^{22}$ At the time, however, the scope of these Boards was very carefully circumscribed, Churchill stressing that 'these methods of regulating wages by law are only defensible as exceptional measures to deal with diseased or parasitic trades' ${ }^{23}$ These arguments were to be returned to in the very different circumstances of the war and post-war problems of the jute industry, a discussion returned to in section IV.

\section{II}

Juteopolis always did well in wartime. After an initial dislocation, it had flourished during the American Civil War, as jute (and linen) goods were in strong demand for tents, waggon coverings and sandbags as well as peace-time uses in bags and sacking. Similarly in the First War, after initial slack trade following the declaration of war, the industry flourished mightily; as the local Year Book noted of 1915 'Dundee can hardly hope to have another year of such unmixed prosperity' ${ }^{24}$ For 1916 the summary was '... a year of richest prosperity to the staple trades of Dundee and district' ${ }^{25}$ Above all, it was the demand for sandbags that drove this 
boom, with demand rising from less than a quarter of a million per month to over 40 million in the course of $1915 .^{26}$

This initial boom was succeeded by a period of continuing strong demand but increasing constraints on supply, both of raw jute and of labour. Raw material imports, which had averaged 200,000 tons per annum in the last pre-war decade, rose to 295,000 in 1915 , but then fell back to a low of 82,000 in $1917 .{ }^{27}$ This fall followed the imposition of controls aimed at limiting demand for shipping. ${ }^{28}$ Labour shortages reflected the opening-up of alternative employment opportunities as well as mobilisation into the forces for male workers. For women, who made up the majority of the jute labour force, there were some alternatives in munitions factories, plus some hard-fought access to previous male preserves such as on the trams and trains. ${ }^{29}$ Labour supply was supplemented by a considerable influx of workers previously in the war-disrupted fishing industry. The striking overall feature of the jute labour market was the strength of demand.

The unsurprising consequence of this level of demand was upward pressure on pay levels, with strikes as employers tried to resist labour's demands, though conceding an underlying upward trend in nominal wage levels. ${ }^{30}$ In these conditions the main union of jute workers, the Dundee and District Union of Jute and Flax Workers (DDUJFW), flourished, doubling its membership between August 1917 and August 1918 to reach twenty thousand. ${ }^{31}$ Another feature of changes common across the wartime UK was the support of state agencies for labour in some aspects of their disputes with employers. In the Dundee case this was most evident in the Ministry of Labour's support for the union in its disagreements with jute employers about how to respond to the limits on production brought about by shortages of raw material. The 
employers wanted to do this by reducing the workforce by redundancies, but with the Ministry’s backing the Union's alternative plan of short-time working prevailed. ${ }^{32}$

The wartime strengthening of local trade unionism in the city was matched by the strengthening of the jute employers. In 1918 they formed the Association of Jute Spinners and Manufacturers (AJSM), and this became a highly effective bargaining body, not only in relation to the unions, but also in discussion with government bodies that from the war onwards were to play a much bigger role in the industry. ${ }^{33}$ These shifting circumstances had no immediate impact on the parliamentary politics of the City. Churchill, having been comfortably re-elected in the two general elections of 1910, was then faced with an election contest during the war, in August 1917, and in defiance of the electoral truce, when he became Minister of Munitions. ${ }^{34}$ The election was contested by the prominent local prohibitionist and pacifist figure, Edwin Scrymgeour, who had stood unsuccessfully in all previous Dundee elections back to 1908.

Churchill won a convincing victory by 7302 votes to 2036, albeit on a turnout of only 43 per cent. ${ }^{35}$ The election debate focussed on the war, with Scrymgeour's advocacy of a negotiated peace leading Churchill to compare him with Lenin. ${ }^{36}$ Though Scrymgeour was a socialist, he got no support from the official Labour party, locally or nationally, whilst Churchill was able to claim the support of both Unionists and Labour. ${ }^{37}$ On the other hand, Scrymgeour undoubtedly did articulate the opposition to Churchill amongst elements of the labour movement in Dundee. Most importantly, he was supported by John Sime, the Secretary of the DDUJFW, and the single most important trade union figure in the city. For Sime, Churchill was 'one of the last men who will do anything for the working classes, unless they compel him by 
vigorous action to do so', and he cited as an example Churchill's failure to support the case for having jute declared a protected occupation. ${ }^{38}$

III

In the war's immediate aftermath the jute industry moved quickly into contraction as wartime demand dried-up. There was also recognition that the resumption of peace was likely to revive competition, not least from India, where the wartime industry had boomed, aided by the diversion of British production from exports to war uses. In the face of these expected problems debate over the future of the industry down to 1922 was dominated by two issues—-trade protection and minimum wage regulation. Both of these were key issues for New Liberalism, and are explored in turn.

Nationally, the war had led to a considerable strengthening of protectionist sentiment, and this was also evident in Dundee. For example, the pre-war idea of a preferential export duty on Bengal's raw jute was revived at the Dundee Chamber of Commerce in $1916 .{ }^{39}$ This proposal was returned to by the jute employers as the war drew to a close, in evidence given to the Government-appointed committee on the position of textiles after the War. ${ }^{40}$ Such plans had clearly been given a fillip by antiGerman sentiment, as Germany had been a major jute manufacturer before 1914. This strategic approach to trade was to feed into what came to be called 'Safeguarding', the idea that certain industries should be protected because of their centrality to warmaking. ${ }^{41}$

Also in the last months of the war a committee was set up jointly by the AJSM and trade unions to look at ways 'to expand the industry after the war'. ${ }^{42}$ This was the 
first time that the two sides of the industry had come together in such a way, though it should be noted that this was far from suggesting harmonious industrial relations in the industry, where a significant strike was occurring in the later months of the war over the length of the working week. ${ }^{43}$ It was against this background that the campaign for the December 1918 election was fought. Churchill stood on the Coalition ticket, 'the 'Coupon', and was not opposed by the Unionists. ${ }^{44}$ At the core of the election debate was the likely nature of the post-war settlement with Germany, and Churchill in his election address emphasized that it was not 'the time for putting forward elaborate programmes of political and social reform' ${ }^{45}$

The Coalition with the Conservatives, which had become a thoroughly protectionist party, was plainly a problem for Liberal free traders. Churchill brought to this issue a long-standing, deep-rooted commitment to free trade. ${ }^{46}$ In his election speeches he sought to play down the significance of the issue, talking of the mandate of the government to make minor protectionist measures, and the case for preference only on existing duties: 'It is not a question of Free Trade or Protection. It is a question of getting our daily bread'. ${ }^{47}$ But this was to be a recurrent source of tension over the remainder of his time in Dundee, with the local Liberal Association unhappy with any slippage from complete free trade. When, in the run-up to 1922, calls for an independent Liberal candidate were pressed, one of the criticisms of Churchill and the Coalition was support for Safeguarding, though Churchill vigorously defended this policy, arguing that 'The Safeguarding of Industries Act arises directly from the resolutions proposed at the Paris conference of 1916 by Mr Asquith and $\mathrm{Mr}$ Runciman. It in no way affects the general principle of Free Trade'. ${ }^{48}$ Pressed by employers on the issue of Indian competition, Churchill stressed that he was a free 
trader, and avoided answering directly a question about a preferential export duty on raw jute, asserting only that 'we must have all the raw material we require before those who caused all this trouble got their share'. ${ }^{49}$

The 1918 election saw a sweeping national victory for the Coalition, and Churchill was returned with his largest majority, along with Wilkie, albeit on only a 47 per cent turnout. ${ }^{50}$ The Unionists did not put up a separate candidate, Scrymgeour stood again as a Prohibitionist, and James Brown, the President of the Dundee Trades Council, stood for Labour. ${ }^{51}$ Local issues, above all about the future of jute, had figured in the campaign although Churchill's somewhat fudged responses were clearly not an obstacle to his re-election. But the condition of the industry soon came into sharper focus in the early months of 1919, as the industry's slump continued, and the AJSM successfully approached the trade unions to make a joint approach to the government in London on the surge in imports of Indian jute manufactures. ${ }^{52}$

The route to getting such joint action was by no means straightforward. This was partly because of wrangling over union representation, with the DDUJFW hostile to involvement of the Dundee Factory and Mill Operatives Union (DFMOU), an organization led by a clergyman and regarded by other Dundee unions as not a real trade union. More important than this was the ambivalence of the DDUJFW about what should be done in response to Indian competition. While the AJSM in 1919 was pressing the case for 'stopping' Indian imports, the union offered only 'general support' for something to be done. ${ }^{53}$

Responding to the statement made by the employers prior to the London meeting the DDUJFW emphasized that 'it must not be assumed we agree with all the statements put forward by the employers on the question of Indian competition'. The unions tended to put more emphasis on the question of raising the wages and 
conditions of Indian workers. Thus, Sime suggested bringing in George Barnes as the government minister responsible for international labour conditions and the contemporary discussions with the International Labour Office. ${ }^{54}$ But the AJSM view was that discussion of wages in India was beside the point: 'such alterations of wages and hours in Calcutta would have no material effect, and what was more important, would have no immediate effect'. ${ }^{55}$

While these discussions were going on the DCC was continuing its pursuit of a preferential duty on the export of raw jute. It saw this issue as needing to be separated from the issue of Calcutta competition with Dundee: it was 'not a purely parochial matter'. ${ }^{56}$ When they met the President of the Board of Trade they agreed with him that what they were looking for was a duty to be used for bargaining purposes. But as he pointed out, if it was used in this way Britain's access to foreign raw materials might be threatened and he noted that 'we might come the most appalling "cropper” in Lancashire if we dealt very lightheartedly with jute’. ${ }^{57}$ Thereafter the issue seems to have been shelved.

At the meeting with the AJSM and DFMOU, Churchill stated that 'the problem appeared to him to be one of extreme difficulty, as any form of prohibition in this case would be against one of the Dependencies of the Empire, and further, any form of protection would be against the Free Trade principles of the Government. Although he was a strong advocate of Free Trade, he was not prepared to say that some modification of Free Trade principles would not be necessary to overcome circumstances, such as had arisen in the jute trade'. But his practical suggestion was limited to the setting-up of a Royal Commission. ${ }^{58}$ 
The following week another meeting at the Board of Trade involved the main trade unions, including the DDUJFW. Sime reiterated the call for a commission of enquiry, stressing the severity of the crisis, and 'If nothing was done Dundee would drop from its status as the third city in Scotland and become of no more importance than Montrose'. While the enquiry was underway Sime called for government control of the jute industry in both Dundee and Calcutta. On protection Sime 'did not suggest that imports should be restricted permanently, but until a proper solution was found restriction of imports of jute goods should be imposed'. ${ }^{59}$

In response to these meetings, the Board of Trade announced a committee of enquiry, which would start work in Dundee at the end of May. ${ }^{60}$ When this committee reported in December its conclusions were very clear against protection. The Committee presented import restrictions as the proposal of the employers, and rejected this idea as 'impracticable’: ‘The committee are unable to recommend artificial means to enable the United Kingdom to compete with another portion of the Empire’. 61

Turning to the unions’ proposals for equalizing competition between Dundee and Calcutta either by raising wages in India to Scottish levels, or imposing the same conditions as under the British Factory Acts, the report deemed these were neither practicable, nor likely to be effective. Wages in India were such that Dundee had to accept a significant loss of markets in the lower quality goods, and the only solution for Dundee was to 'concentrate on the finer grade of goods and specialities not made by the Indian mills'. ${ }^{62}$

In making its report the committee noted that, since the spring, conditions in the industry had markedly improved, though it recognised this improvement was 
unlikely to be permanent. However, across Britain, 1919/1920 was a boom period of post-war 're-stocking', and Dundee participated in that, helped also by specific factors relating to the appreciation of the rupee reducing Calcutta's competitive edge. ${ }^{63}$ As was to be expected there was disappointment amongst the jute employers at the committee's report, but its effect was to kill the issue of protectionism in Dundee jute for the time being. ${ }^{64}$ For the next year the industry and the city were to enjoy a period of relative prosperity that dampened the search for responses to the industry's problems.

IV

Trade Boards were a key feature of the New Liberal legislation under the prewar Liberal government. ${ }^{65}$ The number of workers affected was quite small, and the extent of the impact on these disputed, but for proponents the law marked the establishment of a new principle. The historian R. H.Tawney, who was actively involved in the calls for such intervention, cited the laws as a rejection 'of the doctrine, held for three generations with almost religious intensity, that wages should be settled, as it was said by free competition alone, is one of the most remarkable changes in economic opinion which has taken place in the last hundred years...' ${ }^{66}$ On the other hand, the measure was supported by most Conservatives on paternalist grounds, seeing at as focussed only on assisting those who were unable to help themselves. ${ }^{67}$ The legislation faced almost no opposition in the House of Commons. 68

Churchill, as President of the Board of Trade, was responsible for piloting the legislation through government and parliament. In commending the Bill to his Cabinet 
colleagues he stressed that the intervention would be limited to those trades where a majority of those in the trade supported legislation. He also insisted that the Boards would only be introduced in conditions where wages were exceptionally low, and there were conditions prejudicial to physical and social welfare...'there is no danger of such principles being unwittingly accepted as the normal basis of industry' ${ }^{69}$ Churchill defended this departure from traditional liberal policy, urging that 'decent conditions make for industrial efficiency and increase rather than decrease competitive power' ${ }^{70}$

The question of whether there should be a Trade Board in jute was raised at the time of the original legislation in 1909. One aspect of the drive for that regulation was the especially weak position of women workers, and the women's trade union activist Mary McArthur had made the case for a Board in jute to protect workers who sewed sacks, who were usually women: 'Mr Churchill, it was to be hoped, would not forget the jute workers, for not only was the jute trade one of the lowest paid of the staple trades of the Kingdom, but there was also a considerable amount of sacksewing, which was even worse paid than the jute trade'. ${ }^{71}$ There is no evidence that, at this time, the unions in jute pressed for a Board. ${ }^{72}$

There is also no evidence of Churchill explicitly rejecting the case for jute's inclusion at this time, but as noted above he was keen to emphasize the narrow scope of the proposed legislation: wages had to be 'exceptionally low' and 'conditions prejudicial to physical and social welfare' ${ }^{73}$ Civil Service comment on the proposal concentrated on its likely effect on bag sewers, work largely done at home by women, and suggesting 'It is unpleasant work and therefore done by very wretched people. I don't know that a Trade Board would be of any use; there are so many other forces at work to produce misery. ${ }^{74}$ A proposal by the MP for Montrose, Robert Harcourt, to 
include jute and linen in the industries covered by Boards was opposed by the Dundee Chamber of Commerce, and subsequently dropped. ${ }^{75}$

The scope of Trade Boards was widened during the war, and the legislation was extended in 1918. Where the original law had been fundamentally concerned with the level of wages, hence 'Sweated Industries', the extension, in line with early post-war thinking, focussed on the degree of organization of an industry. ${ }^{76}$ The idea of a Trade Board in jute resurfaced in August 1918, when Sime said he was surprised at the idea, given the high level of unionization in the industry, but welcomed the proposal. ${ }^{77}$ The matter was under active discussion by the AJSM by November 1918, and their initial stance was surprisingly favourable, seeing it as a way of regulating wages at a time of exceptional industrial unrest. ${ }^{78}$ Employers were assured by the Board of Trade that a Trade Board did not involve suggesting jute was a sweated industry, and further reassurance was offered that a minimum wage would not be set until conditions had settled down. ${ }^{79}$

The Board was established at the end of 1919, and set the first minimum wage in June 1920, co-inciding almost exactly with the peak of the post-war boom. ${ }^{80}$ In February 1921 the employers called simultaneously for a wage cut and the abolition of the Board, part of a co-ordinated push by employers against wage regulation, and part of the strong political drive for 'de-control'. ${ }^{81}$ At this time the Union was still calling for a wage increase, but eventually, despite its opposition, a 12.5 per cent cut was agreed by the Board to take effect in September 1921 (further cuts followed down to $1923^{82}$ ). Before that happened, in February of that year, the AJSM approached the Board of Trade to press for abolition. Even when the September cut was secured, it regarded this as inadequate and pressed for further action, and succeeded in getting a further reduction agreed to take effect in February 1922. ${ }^{83}$ 
When the AJSM approached the Ministry of Labour on abolition they argued that the workers were well organised and didn’t need a Board to defend their interests, and that the present level of wages set by the Board was causing unemployment. ${ }^{84}$ Senior figures in the Ministry took a robust view of the employers’ case. A memorandum on the subject noted that the wages set by the jute Board were almost the lowest fixed by any Trade Board in the country, moreover, the document cited an expert's view that 'the simple fact is that there is no market whatever for the manufactured article, and that if wages were reduced to zero it would not affect the position in this respect at all', and went on to say 'it is clearly, therefore, an attempt of the employers to use the slump for breaking down the Trade Board system which, as almost the worst employers in the country, they have always resented'. ${ }^{85}$

The rejection of the employers' case by the Ministry, formally notified in April 1921, led them to approach Churchill in the summer of 1921, and in turn he approached the Ministry of Labour. ${ }^{86}$ In response to him, a senior official in the Board of Trade staunchly defended the Board's role against the view that the industry was in principle one to which the legislation should not have been applied, and that its application was causing unemployment. On the first point, it was argued that even without the recent fresh legislation, jute would have fallen to be regulated under the 1909 Act, as its wage levels showed it to be a sweated industry. On the second point, he stressed that the wages set by the Board were linked to changes in the cost of living, and that with the recent price fall a cut in wages was under consideration. The further argument was made that, in the absence of alternative local employments, the jute workers were in a very poor bargaining position, and therefore they and their unions needed a Board to have any effective power. Finally, it was asserted, the 
problems of the jute industry were of such a magnitude that a cut in wages of any plausible scale was unlikely to much affect the employment level. ${ }^{87}$

The DDUJFW strongly resisted the call for abolition of the Board, and stressed not only the benefits to the workers, but also the previous willingness of the AJSM to use the Board to get agreement on difficult issues in the trade. It was clear to the union by this time that the deflation in the economy was going to lead to strong pressure from the employers for wage reductions. ${ }^{88}$ Churchill came out strongly in support of the employers' case for abolishing the Board. Writing to the Prime Minister in September 1921, he said 'as you will know, I was originally the author of this legislation, but over and again to Parliament I declared that it was to be confined to parasitic trades, and that not trade that was capable of forming an effective trade union should be subjected to this special and invidious control. The original bill has now been extended to all sorts of trades to which it is wholly unsuited, including the powerful Jute trade in Dundee'. He also argued against wage minima on the grounds that 'the trade itself is under competition from India. The capital sunk in the Indian mills was not subject to the British income tax or Excess Profits Duty...Behind them stand relays of Indian labour capable of earning less than one third of the present wage scale’. ${ }^{89}$

Around the time of Churchill's letter, the local Unionist newspaper, the Courier, mounted a vociferous and persistent campaign against the Trade Boards. Editorials on $3^{\text {rd }}, 17^{\text {th }}, 20^{\text {th }}$, and $29^{\text {th }}$ of September 1921 supported the call for abolition. In the last of these the paper attacked the trade unions for their support of the Boards, charging that this was inconsistent with the unions professed concern with unemployment. ${ }^{90}$ The union position was complicated by Sime’s exclusion from the 
Board, because of alleged misbehaviour, but this did not undermine their support for the principle. ${ }^{91}$ In April 1922 the newspaper’s critical commentary continued, suggesting that the Cave Committee, which had reviewed the operation of the Trade Boards, had all but recommended their abolition, and that the Board of Trade should now move to abolish them. ${ }^{92}$ An editorial close to the 1922 election, on $28^{\text {th }}$ September, characteristically suggested that the Boards had 'proved a complete and costly failure', above all in increasing the level of unemployment.

Unemployment was the key issue in Dundee in the early post-war years. After the post-war boom of 1919/20 it rose rapidly to a peak in the winter of 1921/22, reaching perhaps 30 per cent in the jute industry. ${ }^{93}$ Both the parliamentary and popular politics of unemployment, here as elsewhere in Britain, primarily focused not on its reduction, but the relief offered to those who suffered from its effects. In September 1921 Dundee saw a serious breakdown in public order as jute workers entitlement to National Insurance payments became exhausted, and the Parish Council announced it was unable to extend the operation of outdoor relief. ${ }^{94}$ This kind of localised, rowdy street politics was to be increasingly eroded by the rise of national politics and campaigns, and unemployment relief was to become a 'nationalised' issue later in the inter-war period as Parishes and Poor Law Boards lost control of relief, partly as a response to the effectiveness of the local protests. ${ }^{95}$ In Scotland, and in contradiction to the law, outdoor relief to the able-bodied was granted, and in late 1921 central government had indemnified local Parish Councils against potential action by disgruntled rate payers. ${ }^{96}$

This was not the first outbreak of unrest. In September 1919 Churchill had postponed a meeting in the City because of fears of such rowdiness interrupting his public meetings, and the following year similar issues were discussed between him 
and the Chairman of the Liberal Association, especially in relation to disturbances led by unemployed ex-service men. ${ }^{97}$ Partly because of the disruptive effects protests about unemployment had on the conduct of parliamentary politics in Dundee, Churchill was active behind the scenes on this issue. When Sir Montage Barlow reported to Churchill on the situation in the city later in 1920 the focus was still on unemployed ex-servicemen, for understandable political reasons. Barlow’s report fed into a Cabinet appointed committee on unemployment, which Churchill encouraged the creation of, and which explicitly discussed the situation in Dundee. ${ }^{98}$

But with the slump in 1921 the unemployment situation greatly deteriorated. By April of that year fears of unrest led Ritchie to advise Churchill against holding a public meeting in the city. In September, against the background of the protest against the Parish Council noted above, Churchill was again worrying about disruption to possible meetings. ${ }^{99}$ But he was also urging action by the Prime Minister on the unemployment issue. This was done in the same letter already cited in which Churchill attacked the jute Trade Board. It began by saying that 'My discussions here have convinced me that there are very great grounds of complaint against the government's policy on unemployment'. Again, 'policy on unemployment' meant policy on its relief, with Churchill arguing for an extension of National Insurance provision to avoid more of the unemployed becoming reliant on the Parish Councils (who were responsible for poor relief in Scotland until 1929). Churchill linked this to the Trade Board issue by claiming that the wages they set were a major cause of unemployment, and therefore the cost of their actions was falling on the public authorities responsible for unemployment relief. ${ }^{100}$

In this same letter Churchill asserted that 'he certainly did not identify himself with the employer point of view' ${ }^{101}$ But by opposing Trade Boards, Churchill had 
aligned himself clearly with the Unionist opposition and in clear contradiction to the position of the local trade unions. And while he was certainly active in encouraging a positive response to protests about unemployment relief, the very focus on this issue suggested a degree of giving-up on any policy to address the possibility of increasing employment or finding a way to ameliorate the jute industry's plight.

\section{$\mathrm{V}$}

As shown in Table 1 the election of 1922 was a clear defeat for Churchill.

\begin{tabular}{|l|l|}
\hline E. Scrymgeour (Prohibitionist) & 32,578 \\
\hline E. D. Morel (Labour) & 30,292 \\
\hline D.J. Macdonald (Coalition Liberal) & 22,244 \\
\hline W.S. Churchill (Coalition Liberal) & 20,466 \\
\hline R. Pilkington (Independent Liberal) & 6,681 \\
\hline W. Gallacher (Communist) & 5,906 \\
\hline
\end{tabular}

Source: Southgate, 'Politics and representation', p.302. Note that as Dundee was a dual member constituency, each voter had two votes.

The victors were a Labour candidate, E.D.Morel, and the Prohibitionist, Edwin Scrymgeour, who was otherwise (broadly) a Labour supporter. These two represented diverse strands of the new combination that was underpinning the electoral growth of the Labour party. ${ }^{102}$ Morel was a cosmopolitan intellectual with no ties to Dundee, famous for his role in exposing the extraordinary excesses of King Leopold of Belgium's rule in Africa, a founder of the Union of Democratic Control who had spent six months in prison for activities related to his opposition to the war. He had been a Liberal candidate for Birkenhead until his opposition to the war led to his resignation on December 1914, after which he moved increasingly towards the Labour party. ${ }^{103}$ 
Scrymgeour was a very well-known local man, a long-serving City councillor, whose prohibitionism (and abrasive Christianity) had complicated but not ultimately prevented him becoming accepted as a representative of the labour voice in Dundee, though not endorsed by the Labour party. In his idiosyncratic way he was undoubtedly part of the radical movement to the Left in Scotland, symbolised above all by 'Red Clydside’. ${ }^{104}$ The newspaper Scrymgeour edited, the Prohibitionist, celebrated the outcome of the 1922 election as both ‘Britain’s first Prohibitionist MP returned with a marvellous majority’ but also ‘Accompanied by Morel, thus achieving Labour's double victory' ${ }^{105}$ His peculiar appeal is suggested by the data we have from this dual-member constituency, which shows that over 5,000 of his voters were 'plumpers'-people who didn’t use their second vote, but gave one only to him. ${ }^{106}$ The most detailed discussion of the immediate causes of this electoral outcome identified four 'principal agencies of opposition to Churchill' the 'Dundee Irish, the Jute and Flax Worker's Union, the Prohibition Party and, late on the scene, the Communist Party.' 107 The Irish hostility to Churchill was linked to his prominent role in the battle over Irish independence leading up to the 1921 Treaty, and the widespread support in Dundee for the anti-Treaty Sinn Fein. Sufficient support to elect an MP made the Prohibition Party a Dundee peculiarity, though prohibitionism was a popular cause in Scotland in the 1920s. The Party may also have been important as a mobiliser of (newly-enfranchised) women, as we know women were disproportionately in favour of the teetotalist case. ${ }^{108}$ There was also the legacy of Churchill's equivocations over the enfranchisement of women dating back to the early 1900s. In the Edwardian years he had 'developed a very personal antipathy to women’s suffrage ever since the militants began interrupting his perorations'. ${ }^{109}$ 
The strength of support for the newly-formed Communist party is notable, and reflected the strongest form of rejection of the old liberal political economy. The party was closely linked to the 'street politics' noted above, but while this may have gained it some support from those most hostile to 'respectable' parliamentary politics, it may also have meant that the working class vote was less divided than in 1931, when the Communist vote reached its peak at over 10,000. ${ }^{110}$

The DDUJFW's position had hardened against Churchill, and this reflected his perceived indifference to the plight of the city, with Sime frequently arguing that Churchill paid little attention to his pleas for assistance. ${ }^{111}$ The basis of this claim, and the broader issue of Churchill's alienation from the organised working class in the city, is returned to below. But also important to Churchill's loss of support was the division in Liberal and Conservative politics which helped to divide the vote on the anti-Labour side; what has been called 'the utter disarray of the Right' ${ }^{112}$

Discontent over the fiscal stance of the Coalition was a recurrent feature of Churchill’s correspondence with Ritchie. As early as May 1919 Churchill was complaining to him 'least of all do I think there is good ground for complaint from Liberals in regard to the Budget, which lays its only increase of taxation on alcoholic liquors and death duties. I regard, and have always regarded, the giving of Preference to the Dominions on existing duties as a very small matter so long as there is no question of the protective or preferential taxation of food'. ${ }^{113}$

These two linked issues — taxation and protectionism-were key to a growing wedge between Churchill and the Liberals in Dundee. While the Coalition eventually launched a major reduction of public spending ('the Geddes Axe’), 'old-style' Liberals wanted action sooner and sharper. ${ }^{114}$ And, as noted already, belief that the Tories’ protectionist instincts were not being sufficiently resisted was a recurrent 
source of contention. Churchill's political tactics were clear long before the 1922 election. Writing to Ritchie in September 1920 about speeches during a forthcoming visit to Dundee he wrote 'My object, of course, will be to promote the unity of antisocialist forces, and I shall be glad of any facts which will give me guidance as to the local situation in regard to this' ${ }^{115}$

In summer 1921 he welcomed the selection of a second (pro-Coalition) liberal, Macdonald, urging 'We ought at an early date in the Autumn to have a joint meeting at which Mr MacDonald and I would both be present. The lines of cleavage against the two Bolshevik and Labour candidates could then be clearly drawn' ${ }^{116}$ Churchill's focus on the menace of socialism was also a bone of contention with lots of Dundee Liberals, many of whom regarded the Conservatives as the bigger enemy, with their espousal of protectionism. Their fears were clearly justified, as Churchill by early 1922 was in correspondence with the Dundee Unionist Association, extolling not only the virtues of the Coalition, but also floating the idea of a new National Party, for which anti-socialism would be the foundation. ${ }^{117}$

Key problems of Churchill's stance can be seen in the politics of his running mate. MacDonald was a strong supporter of retrenchment, and urged on Churchill the need to emphasize this in trying to maintain Liberal support. ${ }^{118}$ While he was allied with Churchill, his enthusiasm for retrenchment made him seem like an old-fashioned Liberal, happily and explicitly embracing the slogan of 'Peace, Retrenchment and Reform’. For him, retrenchment would involve, for example, an end to National Insurance against unemployment, leaving this provision to trade unions and friendly societies. But while this could be seen as extremely conservative positioning, he also prioritised retrenchment over anti-socialism, regarding the Conservatives as the real obstacle to retrenchment. ${ }^{119}$ By contrast, while also emphasizing retrenchment, 
Churchill argued this was one of the big issues upon which Unionist and Liberals were united. ${ }^{120}$

This confusing amalgam of policy and polemical stances was accompanied in the months leading up to the election by organizational problems amongst Liberals in Dundee. Ritchie died in late 1921, to be succeeded as President by Joseph Philip. Philip resigned in April 1922, to be succeeded by J.C Robertson. Churchill never established the degree of accord with the local Liberals that had existed with Ritchie in post. More obvious was the split in Liberal ranks over their attitude to the Coalition and to Churchill. In the summer of 1922 a vote on whether to support his candidature was passed by 81 votes to 41 . Those in the minority formed a Dundee Liberals Committee, motivated especially by hostility to Safeguarding and government extravagance. They brought in an Independent Liberal candidate, Robert Pilkington. ${ }^{121}$

The 1922 election in Dundee was a spectacle of 'mutual and unedifying bitterness', in which characteristics much of the running was made by Churchill and his allies on the one side, and the Communists on the other. ${ }^{122}$ Churchill's tactic was to patronise Scymgeour as honest but deluded, but treat Morel as a crypto-

Communist: 'Mr. Gallacher is only Mr Morel with the courage of his convictions.' 123 This line of polemic may be seen as being as miscalculated as Churchill's famous speech in the 1945 election, linking a Labour government to the Gestapo. Not only was Morel a long way from being a Communist, as Lenin recognised in characteristic terms: 'Morel is a bourgeois, whose talk about peace and disarmament is a lot of empty phrases'. ${ }^{124}$ But attempting to label him as such showed how far out of touch Churchill was with the local popularity of someone whose long history of anti- 
militarism, including six months in prison for his anti-war activities, had considerable resonance in the city. ${ }^{125}$

By disrupting international trade the First World War accelerated the industrial development of poor countries, especially in Asia, significantly changing the international division of labour. Textiles were at the core of this shift. ${ }^{126}$ Mmost significant for Britain was the upsurge of Indian manufacturing, reflecting the key role of textile production in that country. ${ }^{127}$ Cottonwas central to the shift, with the loss of Britain's market share in the Indian market the single most dramatic, immediate commercial consequence of the War. ${ }^{128}$ While a much smaller industry, the effects of the war on jute were, even more striking, with Dundee's home market being entered by Indian producers on a substantial scale for the first time.

This wartime disruption was not to a pattern which had previously been unchanging. Indian producers had been making gains at their British competitor's expense in both cotton and jute well before the war, though in the former case a loss of market share was compatible with a continuing absolute increase in trade. In jute, , total output faltered even before $1914 .{ }^{129}$ Bby disrupting shipping and raw material supply as well as production and sale of the final product, the war fundamentally shifted the relative position of Dundee and Calcutta, and henceforth the former was never going to recover.

At their broadest these changes involved a profound challenge to the whole architecture of the international economy, and especially Britain’s pre-eminent role within it. The gold standard and free trade regime were now under pressure as never 
before. These issues were to dominate the national economic policy agenda until the crisis of 1931 radically undermined them both. ${ }^{130}$ But alongside this new macroeconomic fragility were the particular problems of those industries and areas most affected. ${ }^{131}$ All of the old export 'staples' were in serious difficulty, but, as suggested above, jute was exceptional in the degree and urgency of its difficulties, combined with the peculiar problem of penetration of the home market by a low-wage producer. This was the context for the politics of Dundee.

Looking back from 1930 Churchill argued that great change had come over public life with the war, 'the issues are not political; they are economic... what (the nation) now asks for is more money, better times, regular employment, expanding comfort, and material prosperity’. ${ }^{132}$ In that light, what seems clear is how far Churchill's approach to Dundee in the four years after the war failed to offer any coherent vision of how prosperity might be restored in Dundee.

On the question of competition with Calcutta in jute, Churchill largely stuck to the norms of pre-war Liberalism and its foundational commitment to free trade, albeit he was willing to concede a small amount of ground to the imperatives of Safeguarding. In a speech in April 1922 he argued that 'The old disputes of Free Trade and Protectionists had no application to present conditions. It was not foreign imports or foreign competition that was injuring this country as a whole, though to a certain extent foreign competition was injuring Dundee. It was the failure of our export trade owing to the collapse of foreign markets. ${ }^{133}$ In fact, foreign competition was harming Dundee more than 'to a certain extent.' Protectionism would have been at best only a limited help, but in the crisis circumstances of the early post-war years Churchill's unwillingness to respond positively to the DDUJFW's call for some action on this front was one important step in alienating trade union opinion. As we 
have seen, there was, at least briefly in 1919, some chance of building on joint employer-trade union pressure on this issue, but the moment was allowed to pass. ${ }^{134}$ Ironically, both Morel and Scrymgeour were anti-protectionists, and showed no sign of following the (equivocal) deviation by the main jute union into the protectionist camp. Before the war Morel had been a strong proponent of free trade, like most Victorian radicals believing it was the route to international peace. In addition, his work on the Congo led him to believe that free trade between free men was the best route to development in Africa. ${ }^{135}$ However, Morel is typical of those on the Left who, as Trentmann emphasizes, stuck largely to anti-protectionism, but ceased to see free trade as any kind of panacea, and started to talk about the need for trade 'regulation'. ${ }^{136}$ What Morel certainly didn’t do, unlike Churchill, was put forward free trade as part of a conservative programme of retrenchment, following the old Liberal logic that in the absence of tariffs for revenue, sound policy required tight limits on public spending lest the weight of other taxes (especially on income) placed an unacceptable burden on the citizenry.

Churchill was right that the meaning of Free Trade had shifted. For most people on the Left, it had become even more of a political issue, closely linked to pacific attitudes to international relations. Conversely, it had become less significant as an economic issue in the pre-war form of a guarantor of cheap food. ${ }^{137}$ In Dundee, as elsewhere in wartime Britain, a new politics of consumption had arisen, often spearheaded by women, and taking both official and unofficial forms. ${ }^{138}$ This had focussed attention much more on state regulation as the route to cheaper and more adequate supplies of food with, as Trentmann suggests, milk as the commodity typically focussed upon. ${ }^{139}$ The Dundee Food Control committee was established in 
August 1917 and was consistently under pressure from Labour and Co-operative interests in the city about its alleged failure to adequately control prices. ${ }^{140}$

For Churchill, on the other hand, advocacy of free trade seemed to have little relationship to his assertive international stance, not least on Russia, where his attitude had alienated working class support far beyond the Communist party. On the Left also, free trade was combined with support for improving wages and conditions of jute workers in Calcutta. ${ }^{141}$ However Utopian this strategy may have been (and impractical as a way of dealing with Dundee jute’s problems), it detached free trade from the conservative trappings it acquired after 1918 in the hands of Churchill and his allies.

When Morel first accepted the candidacy for Dundee in 1920, he emphasized that his focus of attacks on Churchill would be foreign policy. ${ }^{142}$ This issue certainly dominated his campaign. But he linked foreign policy explicitly to Dundee’s economic difficulties, arguing that the instability of the world was encouraged by Churchillian-style belligerence, which in turn reduced trade and hence employment in export industries such as jute. ${ }^{143}$

As noted above, when in September 1921 Churchill wrote to Lloyd George criticising Trade Boards he linked this explicitly to Indian competition. But while clearly characterising Indian competition as ‘unfair', Churchill suggested no remedy for this problem, beyond wage reductions in Dundee. ${ }^{144}$ Churchill's position was certainly not born out of any sympathy for the efforts of India to industrialize; he was especially opposed to allowing such efforts to be aided by tariffs. In 1919, as part of his resistance to any idea of greater self-rule for India, he wrote 'It seems to me monstrous that India should be allowed to put on a protective tariff against British goods while Britain herself remains a free trade country’. ${ }^{145}$ 
The politics of the Trade Board issue were more straightforward than those of free trade. Here it was a case where Churchill lined himself up with employer and conservative forces, and against the explicit support of the unions for the continuation of the Board, a support endorsed by Morel and Scrymgeour. The political issue here was not just the immediately compelling one of trying to find a mechanism to support the wages of Dundonians against the bargaining power of the employers, in the context of a slump. More broadly, the extension of Trade Boards was part of the wartime advance of in the bargaining power of workers that, unsurprisingly, organized labour regarded as the fruits of their commitment to the war effort, and this made their significance extend beyond their (problematic) practical effects in sustaining wage levels.

Overall, Churchill had nothing to offer on the economic issues facing juteopolis. While he was willing to work to ease the pressure on the local authority to pay unemployment relief, for the jute industry itself he could only offer support for the employers' drive to end the wage board and allow unconstrained wage cuts. He opposed protectionism, and when doing so made the understandable but unhelpful comment in a meeting with the jute unions, that 'where competition was between peoples living under wholly different modes of life, Government would have to formulate principles of equity and economy for regulating such competition; these principles were not at present apparent to him’. ${ }^{146}$

This was counsel of despair in the face of the shifting international division of labour. But this was the kind of shift that free trade doctrine had never anticipated. As Peter Clarke has pointed out, as far back as the Tariff Reform controversy, in 1903, Churchill had recognised that international competition would force shifts in activity in ‘old industrial countries' like Britain. Echoing Alfred Marshall’s analysis, he had 
asserted that it was under free trade 'where readjustment of labour and redistribution of capital are more easy, where enterprise is more varied and elastic' that the best results could be expected. But for both Churchill and Marshall the context for such analysis was competition from countries such as Germany and the USA, a slow encroachment on British producers by other sophisticated industrial nations. Such understandings were of little help when competition was from low-wage producers, and in parts of Britain where the idea of a ready transition to what Churchill called 'the more complicated and secondary processes of manufacture’ was so remote. ${ }^{147}$

As Clarke suggests, and as was to be so clearly demonstrated during his tenure as Chancellor of the Exchequer between 1924 and 1929, Churchill's economic ideas had been formed in the late-Victorian/Edwardian heyday of the unmanaged economy and had limited purchase on the economic problems of Britain after 1918. ${ }^{148}$ This was particularly evident in relation to Dundee, which had become an unwitting victim of a shift in the international division of labour. There were no easy remedies for this situation, and Churchill's bafflement is understandable. But the positions he did take in response to these problems, and the baggage they carried with them, were in retrospect almost designed to alienate the organized working-class electors of the city.

Churchill's political trajectory from pre-war Liberal to soon-to-be Conservative had, of course, its idiosyncracies. But the problems he faced in Dundee were an extreme form of those generally faced by Liberals in post-1918 Britain. Collapse of staple export industries rendered the pre-war Liberal combination of free trade and inexpensive social reform unsustainable. Whilst on the socialistic left there was beginning a painful and prolonged shift away from free trade and liberal internationalism towards a 'National Political Economy', liberal political economy in this period showed little sign of coming to grips with the new economic realities. ${ }^{149}$ 
Economic and Social History, University of Glasgow, Lilybank House, Bute Gardens, Glasgow, G12 8RT. Email: jim.tomlinson@glasgow.ac.uk

${ }^{1}$ For the Scottish context, M. Dyer, Capable Citizens and Improvident Democrats. The Scottish Electoral System 1884-1929 (Aberdeen, 1996), pp.135-140.

${ }^{2}$ He stood and lost as a Liberal in West Leicester in 1923.

${ }^{3}$ W. Walker, 'Dundee's disenchantment with Churchill' Scottish Historical Review 49 (1970), pp.85108; T. Pattinson, A Seat for Life (Dundee, 1980); D. Southgate, 'Politics and Representation in Dundee 1832-1963' in J. Jackson (ed.), The Third Statistical Account of Scotland. The City of Dundee (Arbroath, 1979), pp.287-328; M.Gilbert, Winston S. Churchill vol. IV 1917-1922 (London, 1975), pp.863-892. For local politics see J. Kemp, 'Red Tayside? Political change in early twentieth-century Dundee' in C. Whatley et al, Victorian Dundee. Image and Realities (Dundee, $2^{\text {nd }}$ ed. 2011), pp.217238; K. Baxter and W. Kenefick, 'Labour politics and the Dundee working class c.1895-1936' in J. Tomlinson and C. Whatley (eds.), Jute No More. Transforming Dundee (Dundee, 2011), pp.191-219. ${ }^{44}$ The relationship between the War and the decline of liberalism as apolitical force has been debated since the publication of the classic treatment by Trevor Wilson: The Downfall of the Liberal Party 1914-1935 (1966). The debate, very summarily, is between those who see the war as crucial to that downfall, and those who see it only as an accelerator of longer-term socio-economic trends. A recent survey of the debate is in G. Searle, The Liberal Party. Triumph and Disintegration, 1886-1929 $\left(2^{\text {nd }}\right.$. ed. Basingstoke, 2001), pp.124-141. For the survival of liberalism more generally: E. Green and D. Tanner (eds.), The Strange Survival of Liberal England (Cambridge, 2007).

${ }^{5}$ The imperial dimension is explored in depth from different angles in G.Stewart, Jute and Empire. The Calcutta Jute Wallahs and the Landscapes of Empire (Manchester, 1998); A. Cox, Empire, Industry and Class. The Imperial Nexus of Jute, 1840-1940 (Abingdon, 2013) and J. Tomlinson, Dundee and the Empire. 'Juteopolis' 1850-1939 (Edinburgh, 2014).

${ }^{6}$ J. Tomlinson, 'Responding to globalization? Churchill and Dundee in 1908' Twentieth Century British History 21 (2010), pp.257-280; the Lib-Lab pact did not apply in Scotland, but Wilkie seems to have retained membership of the Liberal Party until at least 1910.

${ }^{7}$ M. Freeden The New Liberalism (Oxford, 1978); P. Clarke, Lancashire and the New Liberalism (Cambridge, 1971).

${ }^{8}$ On the Conservatives, see E. Green, The Crisis of Conservatism. The Politics, Economics and Ideology of the British Conservative party, 1880-1914 (London,1996); on Labour, D.Tanner, Political Change and the Labour Party (Cambridge, 1990).

${ }^{9}$ Searle, Liberal Party, passim.

${ }^{10}$ B. Lenman, C. Lythe, E. Gauldie, Dundee and its Textile Industry 1850-1914 (Dundee, 1969).

${ }^{11}$ Conversely, very little jute production took place elsewhere in Britain: Dundee and jute were largely synonymous.

${ }^{12}$ M. Daunton, Britain and globalization since 1850: I. Creating a global order' Transactions of the Royal Historical Society 16 (2006), pp.1-38; K. O.Rourke, 'From empire to Europe: Britain in the world economy' in R.Floud, J.Humphries and P.Johnson (eds.), The Cambridge Economic History of Modern Britain, (Cambridge, 2014), pp. 60-94.

${ }^{13} \mathrm{~S}$. K. Masrani, 'International competition and strategic response in the Dundee jute industry during the inter-war and post war. The case of Jute Industries, Buist Spinning, Craiks and Scott and Fyfe' Unpublished PhD. Dissertation, St Andrews, 2010). Jute was clearly very different from cotton, where the protectionist debate in Lancashire largely focussed upon the Indian market.

${ }^{14} \mathrm{~J}$. Tomlinson, 'Orientalism at Work? Dundee's response to competition from Calcutta, circa 1870-

1914’ Journal of Imperial and Commonwealth History 43 (2015), pp.807-830.

${ }^{15}$ A. Marrison, British Business and Protection 1905-1932 (Oxford, 1996).

${ }^{16}$ S. Pollard, Britain's Prime and Britain's Decline. The British Economy 1870-1914 (London, 1989).

${ }^{17}$ Churchill, 'For Liberalism and Free Trade', Dundee, no date. Copy in Churchill Archive, Churchill

College, University of Cambridge, CHAR 9/31/66, pp. 7, 8, 29.

${ }^{18}$ There was a Labour candidate for the by-election, Stuart, who was also strongly pro-free trade, and argued for the strengthening of the Indian Factory Acts as the right response to Indian competition. Churchill objected to this, arguing that factory legislation should not be pursued as a means of reducing imports, but only as genuine social protection: Tomlinson, 'Churchill', pp.274-276.

19 P. Addison, Churchill on the Home Front 1900-1955, (London, 1992), p.66.

${ }^{20}$ Just before the Dundee election he had fought and lost a bye-election in Manchester North West. 
${ }^{21}$ Addison, Churchill, pp.51-81.

${ }^{22}$ Trade Boards were not universally welcomed on the Left: see J. Thompson, 'Political economy, the labour movement, and the minimum wage 1880-1914' in Green and Tanner, Strange Survival, pp. 6288.

${ }^{23}$ Addison, Churchill on the Home Front, p.78.

${ }^{24}$ Dundee Year Book (hereafter DYB) 1915 (Dundee 1916), p.21.

${ }^{25}$ DYB 1916 (1917), p.16.

${ }^{26}$ E. M. H. Lloyd, Experiments in State Control (Oxford, 1924), pp.36, 66.

${ }^{27}$ Board of Trade, Jute Working Party (1948), table VII. J. Day 'The jute industry in Scotland' in D.Jones et al, Rural Scotland During the War (Oxford, 1926), pp.267-305.

${ }^{28}$ Controls in jute were easier to operate than in industries such as linen, given the limited range of outputs and the single source of supply of the raw material: P. Ollerenshaw, 'Textile business in Europe during the First World War: the linen industry, 1914-18’ Business History 41 (1999), p.71. ${ }^{29}$ N. Glen, 'Of myth and men. Dundee women's experiences working and organising for change in juteopoliis in the Great War and after' (Unpublished MA thesis, Dundee University, 1997).

${ }^{30}$ DYB 1914, pp.16-24; DYB 1915, pp.17-27; DYB 1916, pp.16-27.

${ }^{31}$ W. Walker, Juteopolis. Dundee and its Textile Workers 1885-1923 (Edinburgh, 1979), pp.394-5.

32 The National Archives: Public Records Office (hereafter TNA:PRO) NATS 1/1178 John Sime to F. McLeod 11 Jan. 1918; NATS 1/1179 W. Henderson to F. McLeod 28 Feb. 1918. Dundee University archives (hereafter DUA) MS84/3/1 Association of Jute Spinners and Manufacturers (hereafter AJSM), meetings 17 Jan., 24 Jan., 15 Feb., 15 Mar. 1918.

${ }^{33}$ Though a more informal employers body seems to have had a longer history - there is reference to a 'Dundee Spinner and Manufacturers Association' in the (Dundee) Advertiser 8 Jan. 1913 (cutting in CHAR 5/15/1).

${ }^{34}$ In line with the conventions of the time, and as in 1908 when he was appointed President of the Board of Trade, Churchill had to resign his parliamentary seat on being given a new Ministerial job. ${ }_{35}$ (Dundee) Courier, 4 Aug. 1917.

${ }^{36}$ Courier 13 July 1917; during the campaign Churchill expressed support for temperance ideas, and emphasized that the election was not about Scrymgeour's prohibitionism: Courier 28 July 1917; For Churchill's 1917 election address (which made no mention of Scrymgeour), CHAR 5/19/18-21 26 July 1917.

${ }^{37}$ Courier 25 July 1917, Courier 28 July 1917; acceptance speech by Clementine Churchill, Courier 4 Aug. 1917.

${ }^{38}$ Letter to Courier, July 1917.

${ }^{39}$ Dundee City Archives (DCA) GD/CC/4/9 Dundee Chamber of Commerce (DCC) minutes 20 Jan. 1916.

40 Courier 14 June 1918; see also Scotsman 14 June 1918; 'Report of the Departmental Committee appointed by the Board of Trade to consider the position of the Textile Trades after the War' Cd. 9070 BPP 1918, vol. III.

${ }^{41}$ R. Boyce, British Capitalism at the Crossroads, 1919-1932 (Cambridge, 1987), pp.82-90.

42 Courier 20 Aug. 1918; DUA MS 84/3 (2) 26 Sep. 1918 for Sime’s call for Industrial Council.

${ }^{43}$ Courier 2 Oct. 1918 and DUA MS 84/3/1 (3) 11 Oct. 1918. But the problem of hours of work dogged discussion between employers and unions, with employers wishing to revert to a 55 hours week as more raw jute became available.

${ }^{44}$ CHAR5/20/13-15. In Churchill's letter to George Ritchie, President of the Liberal Association, 5 Nov. 1918, he says that he hopes the Tories will support him, and Labour won't put anyone up against Wilkie, so the two will be easily returned.

${ }^{45}$ Ibid, CHAR 5/20/36 'Draft election address'.

${ }^{46}$ P. Clarke, 'Churchill's economic ideas, 1900-1930'in P.Addison (ed.), R. Blake and W. Louis (ed) Churchill (Oxford, 1993), pp.79-95.

${ }^{47}$ Courier 19 Nov.1918; CHAR 5/21/6 Churchill to Ritchie 9 May 1919

${ }^{48}$ CHAR5/26/66 Churchill to Ritchie 18 Apr. 1922; see also CHAR 27/57/ 101-125.

${ }^{49}$ Address to DCC, Courier 11 Dec. 1918.

${ }^{50}$ Courier 30 Dec. 1918. The local Unionists endorsed Wilkie: Baxter and Kenefick, 'Dundee’, p.205.

${ }^{51}$ Scrymgeour styled himself the 'real labour candidate' whatever the label: Courier 23 Nov. 1918.

${ }^{52}$ DUA MS84/5/1(7) AJSM joint meeting with unions 4 Mar. 1919; though at first they had thought of making an approach on their own: DUA MS84/3/1(3) meeting of 13 Jan. 1919

${ }^{53}$ DUA MS84/3/1 (2) AJSM Association meeting 13 February; DUA MS84/3/1 (3) AJSM General committee meetings 3 Feb, 4 Feb, 25 Feb, 6 Mar., 7 Mar., 10 Mar. 1919. 
${ }^{54}$ DUA MS 84/5/1 (7) AJSM joint meeting with unions 4 Mar. 1919 ; Tomlinson Dundee and the Empire, 112-115.

${ }^{55}$ DUA MS84/5/1 (7) Meeting with DFMOU 11 Apr. 1919.

${ }^{56}$ DCA DCC GD/CC/4/10 Minutes of 25 Nov. 1919.

${ }^{57}$ Ibid., Minutes 5 Feb. 1920.

${ }^{58}$ DUA MS84/3/1 (2) 15 Apr. 1919.

${ }^{59}$ Courier, 18 Apr. 1919.

${ }^{60}$ DUA MS84/3/1 (3) AJSM General committee meeting, 20 May 1919.

${ }^{61}$ Courier, 23 Dec. 1919.

${ }^{62}$ Courier, 23 Dec. 1919.

63 Courier 31 Dec. 1919.

${ }^{64}$ Courier, 24 Dec. 1919.

${ }^{65}$ S. Blackburn, A Fair Day's Wage for a Fair Day's Work? Sweated labour and the Origins of Minimum Wage Legislation in Britain (Aldershot, 2007).

${ }^{66}$ Cited in Blackburn 'Ideology and social policy: the origins of the Trade Boards Act' Historical Journal 34 (1991), p.43.

${ }^{67}$ E.Green The Ideologies of Conservatism (Oxford, 2002), pp. 86,268.

${ }^{68}$ Blackburn, A Fair Day's Wage; there was only one speech against at second reading: Hansard (Commons) vol. 4 1908/09, cols. 342-411.

69 TNA: PRO CAB37/97/13 'Sweated Industries’ by W.S. Churchill 27 Jan. 1909; TNA: PRO CAB 37/98/42 'Draft of Trade Boards Bill’ by W.S. Churchill, 12 Mar. 1909. This memo is in CHAR11/16/ 251. See also his contribution to the second reading of the Bill, Hansard (Commons) vol. 4 1908/09, cols.387-405, where he cited John Stuart Mill in support of the proposition that "General low wages never caused any country to undersell its rivals; nor did general high wages ever hinder it." (col.387). But he also stressed that it was not applicable to staple trades (cols. 388-9) and 'I am strongly opposed to the extension of this Bill to the organised trades of the country' (col.405).

${ }^{70}$ Liberalism and the Social Problem (London,1909), p.32.

${ }^{71}$ CHAR 11/16/187-192 'List of trades from Miss Black, Miss Macarthur and Mr. Mallon’. Jute and linen was described as a 'very badly paid factory trade in which women rapidly displacing men. Many women earning $8 \mathrm{~s}$ and $9 \mathrm{~s}$ a week, and men in the trade as low in some cases as 11s3d. Centralised and easily dealt with'; Courier 6 Feb. 1909.

${ }^{72}$ Walker, Juteopolis. p.420.

${ }^{73}$ CHAR 11/16/251-2 Covering note by Churchill to draft Bill, 12 Mar. 1909.

${ }^{74}$ CHAR 11/16/202 'Comment by C.E.C' 2 Feb. 1909.

${ }^{75}$ Courier 14 June 1909; this idea never got as far as the House of Commons.

${ }^{76}$ D. Sells, The British Trade Boards System (London, 1923), pp. 4-5.

${ }^{77}$ Advertiser 20 Aug.1918 industry (these figures are probably exaggerated).

${ }^{78}$ Cf Walker, Juteopolis, p.419.

${ }^{79}$ MS 84/3 (2) AJSM meetings 25 Nov., 9 Dec. 1918, 28 Aug. 1919.

${ }^{80}$ Sells, Trade Boards System; the wages set by the Board are detailed in DUA:MS84/2 AJSM Annual Report 1939, Appendix H.

${ }^{81}$ Sells, Trade Boards System, pp.243-5; R.H.Tawney, 'The abolition of economic controls 1918-1921' Economic History Review 13 (1943), pp.1-30.

${ }^{82}$ DUA.: MS 84/2 AJSM Annual Report 1939, appendix H.

${ }^{83}$ DUA: MS84/2 AJSM Annual Report 1939, Appendix H; DUA MS 84/3 (2) AJSM meetings 1 Feb. 1921, 15 Apr.1921, 17 June 1921; Walker, Juteopolis, pp.423-4.

${ }^{84}$ TNA: PRO LAB2/842/TBM114/18/1921 F. Cathro, secretary of the AJSM, to Minister of Labour $3^{\text {rd }}$ February 1921.

85 TNA: PRO LAB2/842/TBM114/18/1921 Humbert Wolfe to Secretary 10 Feb.1921.

${ }^{86}$ Ibid., letter on behalf of the Minister to AJSM, 14 Apr.1921.

${ }^{87}$ TNA: PRO LAB 2/248/TBM114/18/1921 T.J. Macnamara to Churchill 25 Aug. 1921, covering 'Trade Board for the Jute Industry.'

88 TNA: PRO LAB2/842/TBM114/18/1921 DDUJFW to Minister of Labour 21 Feb.1921; Deputation of Dundee Jute workers to the Minister of Labour, 1 Mar. 1921. The opposing positions of the employers and unions were set out in detail at the Trade Board meeting in Feb. 1921, see Ibid., 'Report on the discussion, at the meeting of the Jute Trade Board on February $16^{\text {th }}$ and $17^{\text {th }}$.

89 CHAR 5/24 Churchill to Prime Minister 23 Sep. 1921.

90 This was part of a nationwide employer and Conservative campaign against the Boards, which was also strongly supported by the Treasury in the context of public spending cuts: R. Lowe, Adjusting to 
Democracy. The Role of the Ministry of Labour in British Politics, 1916-1939 (Oxford, 1986), pp.6061, 99-100, 102-104.

${ }^{91}$ For union support for the Boards see Courier 26 Feb 1921, 19 Jan 1922, 21 Jan. 1922; protests at Sime's dismissal Telegraph 3 May 1922; the Board of Trade refuses to accept Sime's re-nomination Courier July 181922.

92 This exaggerated the Cave Committee's recommendations, though these were highly restrictive: see Sells, Trade Boards System, pp.248-257; for the subsequent development, D, Sells, British Wage Boards. A Study in Industrial Democracy (Washington D.C.,1939), pp.251-265.

${ }^{93}$ Precise reliable data for the industry or city is not available for these years, but the numbers reported in the local press (Courier 19 December 1921) broadly match those identified in national studies: J.Hilton, 'Statistics of unemployment derived from the working of the unemployment insurance Acts' Journal of the Royal Statistical Society 86 (1923), Appendix 1.

${ }^{94} \mathrm{M}$. Petrie, 'Public politics and traditions of popular protest: demonstrations of the unemployed in Dundee and Edinburgh, c.1921-1939’Contemporary British History 27 (2013), p.493.

95 J.Lawrence' The transformation of public politics after the First World War' Past and Present 190 (2006), pp.185-216; Petrie, 'Public politics', p.496.

${ }^{96}$ I. Levitt, Poverty and Welfare in Scotland 1890-1948 (Edinburgh, 1988), pp.104-151.

${ }^{97}$ CHAR 5/22/20-22 letter Town Clerk to Churchill 18 Aug. 1920; CHAR 5/21/11 and 21 WSC to Ritchie, 9 Sep., 25 Sep.; CHAR 5/22/ 25 Churchill to Ritchie 29 Aug.1920.

${ }^{98}$ CHAR 5/22/ 62-3 'Dundee', which argues that a big obstacle to employment of disabled exservicemen is the Trade Board's wage of 50 shillings per week for men, as opposed to 35 shillings for women. Barlow's report is at CHAR 5/22/64-7.

${ }^{99}$ CHAR 5/24/ 26-50 Ritchie to Churchill 15 Apr. 1921; 5/24/76-100 Churchill to Ritchie 11 Sep. 1921.

100 CHAR 5/24/94-9 Churchill to Lloyd George 23 Sep. 1921.

101 Ibid., 98.

102 The party had been making significant gains in local election from 1919: Baxter and Kenefick, 'Dundee', pp.205-206.

${ }^{103}$ C. Cline, E.D. Morel, 1873-1924. Strategy of Protest (Belfast, 1980); D. Mitchell, The Politics of Dissent. A Biography of E.D.Morel ( London, 2014); C. Cline, Recruits to Labour. The British Labour Party 1914-1931 (Syracuse, 1963).

104 J. Kemp, 'Drink and the labour movement in early twentieth-century Scotland with particular reference to Edwin Scrymgeour and the Scottish Prohibition Party’ (Unpublished PhD dissertation, Dundee University, 2000); Baxter and Kenefick, 'Dundee', p.207.

${ }^{105}$ Prohibitionist 18 Nov. 1922. Prior to the election, he had used the paper to conduct his feud with local Labour figures, whilst attacking them for not supporting him as a second Labour candidate in the election. See, for example, Prohibitionist 11 Mar. 1922, 6 May, 1922, 21 June 1922, 22 July 1922, 28 Oct.1922, 4 Nov. 1922.

106 Southgate, 'Politics', p.303. This tactic was urged by Scymgeour: Prohibitionist 11 Nov. 1922, 18 Nov. 1922

${ }^{107}$ Walker, 'Dundee’s disenchantment', p. 91.

108 Kemp, 'Drink and the labour movement'.

109 Searle, The Liberal Party p.118.

${ }^{110}$ For Dundee’s politics after 1922, M. Petrie, "”Contests of vital importance”: by-elections, the Labour party, and the reshaping of British radicalism, 1924-1929’ Historical Journal 60 (2017), pp.121-148.

${ }^{111}$ Walker, Juteopolis, p.440.

112 Southgate, 'Politics and representation', p.312.

113 CHAR 5/21/5-6 Churchill letter to Ritchie’ 9 May 1919.

${ }^{114}$ C. Hood and R. Himaz, A Century of Fiscal Squeeze Politics: 100 years of Austerity, Politics and Bureaucracy in Britain (Oxford, 2017).

${ }^{115}$ CHAR 5/22 91-2 Churchill to Ritchie 23 Sep.1920.

${ }^{116}$ CHAR 5/24/31 Churchill to Ritchie 22 June 1921.

${ }^{117}$ CHAR 5/26/64 'Current political points' (n.d. but Apr. 1922).

118 CHAR 5/26/76 Philip to Churchill 25 Apr. 1922.

${ }^{119}$ DUA MS 93/1/8/2/9/1/3 Speech 13 June 1921; 93/1/8/2/9/1/1 Macdonald to Churchill 30 May 1922.

120 Advertiser, 8 Apr. 1922.

${ }^{121}$ CHAR 5/27/ 53-4 J. Robertson to Churchill, 13 June 1922; Southgate, 'Politics and representation', 314. Some of the difficulties in Dundee Liberalism at this time are nicely indicated by 36 
the fact that Professor Steggall, who, in proposing the amendment in support of Churchill and Robertson, said he 'loathed the Coalition': CHAR 5/27/40 Notes by W. Macdonald on Liberal Association meeting 12 June 1922.

122 Southgate, 'Politics and representation', 315. Much of the course of the campaign can be tracked through the two main local newspapers, both of which carried extensive verbatim reports. Paterson, $A$ Seat for Life, also conveys the flavour well,. For the Communist view, B. Stewart, Breaking the Fetters (London, 1967), p.127; W. Gallacher, Last Memoirs (London, 1966), p.170; see also R. Rhodes James, Churchill: a Study in Failure 1900-1939 (Harmondsworth, 1973), pp.191-192.

${ }^{123}$ Gilbert, Churchill vol. IV, p.878.

${ }^{124}$ V.I. Lenin, 'British pacifism and the British dislike of theory' Collected Works vol 21, (Moscow, 1974), p.261.

${ }^{125}$ Walker, Juteopolis, pp.451-463; Baxter and Kenefick, 'Dundee’, pp.205-207.

${ }^{126}$ G. Clark, ‘Why isn’t the whole world developed? Lessons from the cotton mills’ Journal of Economic History 47 (1987), pp.141-174.

127 The other big gainer in Asia was Japan: see F. Dickinson, War and National Re-invention: Japan in the Great War 1913-1919 (Cambridge:Mass, 1999); the growth of textile production and exports was a large part of the economic aspect of Japan's 're-invention': M. Rose (ed.), International Competition and Strategic Responses in the European Textile Industries after 1870 (London, 1992).

128 J. Tomlinson, 'The First World War and British cotton piece exports to India' Economic History Review 32 (1979), pp.494-506; B. Tomlinson, The Political Economy of the Raj 1914-1947 (Cambridge, 1979).

${ }^{129}$ Lenman et al, Dundee and its Textile Industry

${ }^{130}$ Boyce, Britain at the Crossroads.

${ }^{131}$ Garside, British Unemployment, pp.203-277.

${ }^{132}$ W. Churchill, Thoughts and Adventures, cited in Southgate, 'Politics and representation', p.316.

133 Advertiser 8 Apr. 1922.

134 There was a similar brief moment in Lancashire in 1921 when employers and unions came together to protest at Indian import tariffs on British cotton goods: B. Chatterji, Trade, Tariffs and Empire. Lancashire and British Policy in India (Oxford, 1992), p.209. In general the cotton unions seem to have been passive on the issue of Indian competition: A. Fowler, Lancashire Cotton Operatives and Work, 1900-1950, (Aldershot, 2003), pp.74-107.

135 Cline, Strategy of Protest; Mitchell, Politics, pp.21,30; Morel believed that opening-up international markets to African farmers was the key to their prosperity.

${ }^{136}$ F. Trentmann, 'The strange death of free trade: the erosion of 'liberal consensus' in Great Britain, c.1906-1932’ in E. Biagini (ed.), Citizenship and Community: Liberals, Radicals and Collective Identity in the British Isles 1865-1931 (Cambridge, 1996), 219-250; Trentmann, Free Trade Nation (Oxford, 2008), pp.251,258.

${ }^{137}$ F. Trentmann, 'Wealth versus welfare: the British left between free trade and national political economy before the First World War' Historical Research 70 (1997), pp.70-98.

138 Trentmann, 'Bread, milk and Democracy: consumption and citizenship in twentieth century Britain' in M. Daunton, and M. Hilton (eds.), The Politics of Consumption (London, 2001), 129-163.M. Hilton, 'The female consumer and the politics of consumption in twentieth century Britain' Historical Journal 45 (2002), pp.103-128; K. Hunt, 'The politics of food and women’s neighbourhood activism in First World War Britain’ International Labour and Working-Class History 77 (2010), pp.8-26.

${ }^{139}$ For example, discussion of municipalisation of the milk trade, Courier 10 Dec. 1918, milk prices Courier 3 Aug. 1918 and 17 Sep. 1919, security of supply, Courier 7 June 1918, costs of distribution, Telegraph 16 May 1919.

140 Courier 14 Aug. 1917, Telegraph 6 Sep. 1917, Courier 3 Sep. 1918. Scrymgeour was highly active on this issue, being a Council member with responsibilities for regulation of the grocery trade.

141 Tomlinson, Dundee and the Empire, pp.103-120.

${ }^{142}$ LSE Archive, Morel Papers F2 1/7 Morel to D. Watt, 12 May 1920; Roberts Smillie to E Morel 22 Aug. 1920.

${ }^{143}$ Cline, Strategy of Protest, pp.132,135.

144 The previous year Churchill had defended 'dumping' of imports in the British market as having a welcome effect on 'the uneconomic demands of labour': cited in Trentmann, Free Trade Nation, p.303.

145 CHAR 2/106/162 Churchill to Montagu 19 Dec. 1919.

146 DUA MS84/3/1 (2) 15 Apr. 1919.

${ }^{147}$ Clarke, 'Churchill’s economic ideas', pp.85-6.

148 Ibid., pp.93-4. 
${ }^{149}$ F.Trentmann, ''Wealth versus welfare: the British Left between free trade and national political economy before the First World War' Historical Research 70 (1997), pp.70-98. 